\title{
MUSICALIDADE EXTRAVIADA
}

O nome desta apresentação partiu de uma imagem encontrada na prosa poética "Piedra fundamental", de Alejandra Pizarnik (1997, 48-50), publicada pela primeira vez em 1971 num livro denominado, precisamente, El infierno musical. Em um curto fragmento narrativo, a voz lírica se lembra de um antigo desejo íntimo de fixar, mediante a música, um ponto seguro de partida e de chegada, "tener una patria", percursos que fossem "en unión y fusión con el lugar". Mas a música se movia, se distorcia e se contorcionava imprevisível. O ser decide, então, abandonar a música traidora, e, uma noite, no circo, uma linguagem conformada pelos sons do galope de cavalos lhe anuncia uma possível salvação: "Escribe, porque estas palavras son fieles $y$ verdaderas". Consumada a mutação, a voz nos diz que fala "para aleccionar a la que extravió en mi su musicalidad".

A promessa de fidelidade das palavras, sabemos, não foi cumprida; a própria Alejandra acaba nos confidenciando outras traições, "una trampa, un escenario más". O percurso que vemos nessa prosa poética nos atingiu especialmente na hora de apresentar esta edição da revista Caracol, porque nele se insinuam diversas e contraditórias representações das relações entre linguagem verbal e linguagem musical que podemos encontrar nos discursos da crítica e das ciências. O verbal como passível de "fixar", de produzir um referente "seguro"; o musical como "primeiro" e "interior"; as perguntas sobre a dominância de um sobre o outro na palavra cantada; a capacidade exclusiva do verbal para explicar outras linguagens, assumida na linguística a partir de Benveniste (1974); o papel de ambas (música e língua) na construção de "pátrias" ou de outras identidades, e, sobretudo, o extravio que supõe pôr ambas as linguagens em relação. Extravio que consideramos não apenas errância, mas também necessidade de sair dos caminhos já traçados para abordar cada uma dessas dimensões separadamente, subir em "un tren algo salido de los rieles", como Pizarnik descreve essa 
música indômita na sua prosa.

Assim, organizamos a ordem dos artigos para este dossiê da Caracol dedicado ao tema "Música e linguagens" conforme os tipos de relação entre linguagem verbal e linguagem musical nos quais cada texto indaga ou se situa, isto é, conforme o modo como essas dimensões se extraviam em cada uma das propostas que aqui damos a conhecer.

O dossiê começa por um artigo, o de Enea Zaramella, "Una escucha al Contrapunteo latinoamericano de Fernando Ortiz", no qual parece inverter-se a relação explicativa tradicional: é a música, mediante a metáfora, a que explica outras linguagens, e estas se valerão dela para descrever o funcionamento social. A obra do antropólogo cubano Fernando Ortiz é abordada por Zaramella como uma variação de perspectivas na qual a imagem do contraponto dá conta da simultaneidade de diversos processos, possibilidade própria do musical, e que na linguagem verbal deve ocasionar um desdobramento narrativo ou, como no caso estudado, de (auto)tradução. O autor detecta, ainda, o recurso de Ortiz ao funcionamento da música para diversos componentes da sua reflexão sobre o desenvolvimento de Cuba, tais como o "ritmo" histórico ou para o conceito de "transculturação".

Os três estudos subsequentes têm vários aspectos em comum: abordam formas musicais delimitadas como gêneros na cultura de massa, observam a inserção e os papéis dessas séries no conflito da formação sócio-histórica em que circulam, e discutem sobre delimitações identitárias relacionadas à produção e à escuta nesses gêneros. A sequência que propusemos tem a ver com o modo como focalizam, nas suas análises, relações entre materialidade musical, materialidade verbal e outras linguagens.

$\mathrm{O}$ artigo "Topografia, personagens marginais e identidade em letras de samba e de tango", de Andreia dos Santos Menezes, circunscreve resultados de uma tese de doutoramento que se debruçou sobre o período em que o samba carioca e o tango portenho se consolidaram como gêneros 
delimitados e entraram na indústria do rádio e do disco. Menezes indaga, a partir de um instrumental dos estudos discursivos de cunho linguístico e em diálogo com a historiografia musical de ambos os países, o confronto polifônico entre perspectivas outsiders e disciplinadoras. Essa observação é o lugar de onde se propõe a abordar uma contradição constitutiva da presença desses gêneros no campo cultural dos dois países: serem considerados representativos do "nacional", inclusive pelos poderes hegemônicos, e albergarem perspectivas e vozes que resultam em claras antíteses dos modelos dispostos por esses poderes.

Em "Microfacismo en el rock argentino. Una enunciación novedosa en El salmón, de Andrés Calamaro”, Sergio Daniel Quintana examina o que ele considera um sintoma de deslocamento no modo como, no rock argentino, é articulada uma posição enunciativa dissidente. Como o anterior, este artigo também está concebido a partir da análise do discurso, mas em um diálogo com a crítica musical de linha sociológica. $\mathrm{Na}$ análise de três composições de Andrés Calamaro, um dos músicos mais representativos desse gênero nas décadas de 1980 e 1990, Quintana consegue mostrar a presença de uma política de construção identitária não dicotômica, materializada em um enunciador que alterna posicionamentos ecoando muito daquilo que ele próprio expõe para distanciar-se. $\mathrm{O}$ artigo integra, para tanto, uma leitura de múltiplas ressonâncias intertextuais que vinculam essas composições, pela letra e pela música, com diversos antecedentes na mídia e na literatura desse país.

O gênero musical abordado por Felipe Oliver em 'Narcocorridos atípicos en la música norteña contemporánea. Ejemplos y reflexiones” é uma variedade do tradicional "corrido" mexicano desenvolvida a partir do crescimento do narcotráfico no norte do país. O caráter atípico das duas composições analisadas por Oliver reside no perfil de anti-herói que se representa nas suas letras ou que nelas se marca como voz e, no caso do segundo narcocorrido, na sua inserção em um espaço de hierarquia mais 
alta na cultura de massa: uma série televisiva norte-americana. A reflexão de Oliver lança mão de caracteres historicamente formulados para tentar descrever a identidade nacional mexicana, e em especial da região Norte do país na sua configuração, entrando em diálogo, para tanto, com pensadores de diversas épocas como Roger Bartra, Octavio Paz e Heriberto Yépez, e com estudiosos atuais que deram atenção ao narcocorrido.

No último artigo do dossiê, o extravio que propusemos culmina sua inversão: a música é evocada pelo significante da materialidade verbal. Em um trabalho de crítica literária, Cecilia Corona Martínez estuda aspectos da escrita de quem também fora um músico profissional. Assim, "Armonías literarias: la música en algunos cuentos de Daniel Moyano" indaga, em três narrações desse escritor argentino, o que a autora identifica como a "presença do musical". Já aludida nos títulos dos contos mediante termos como "cantata", "flauta" ou "violín", a música é crescentemente relacionada à possibilidade de salvação humana e de transcendência. Para a autora, o musical intervém nesses contos com função modelizadora, incidindo em diversos níveis compositivos dos textos e contribuindo para construir um discurso contrahegemônico.

Na seção "Vária", este número de Caracol inclui dois artigos. O de Alejo López, 'Ni de aquí ni de allá: la articulación entre poesía niuyorriqueña y tradición latinoamericana en la obra de Miguel Algarín y Tato Laviera” contrapõe as poéticas desses dois nomes relacionados à denominada "diáspora puertorriqueña" nos Estados Unidos. Segundo o autor, enquanto o primeiro desses poetas se inscreve dentro da tradição de Neruda no que diz respeito a certa forma tradicional de articulação entre literatura e política, o segundo deles, Tato Laviera, resgata o acervo cultural afro-antilhano para debater sobre o caráter híbrido, transmutável e em permanente mobilidade da intersticial identidade niuyorriqueña. O trabalho contribui teoricamente para a discussão da extraterritorialidade latino-americana nos Estados Unidos, ao revisar o corpus dessa parcela literária a partir de cate- 
gorias pós-coloniais e dos estudos culturais.

O trabalho de Mateo Paganini, "La Monja Alférez, problemáticas de género en el estudio de época", tem como assunto o texto supostamente autobiográfico atribuído a Catalina de Erauso, personagem do século XVII que viveu entre a Espanha e a América assumindo diversas identidades masculinas. Paganini reexamina diversas linhas interpretativas em estudiosos dos séculos XIX e XX, tanto acerca da personalidade de Erauso como das possíveis motivações e funções da escrita do próprio texto, revisando, para tanto, reflexões sobre o gênero autobiográfico. $\mathrm{O}$ autor critica uma abordagem, que caracteriza como "precipitação diagnóstica", que pretende classificar a personagem a partir de noções da atual teorização sobre gênero e sexualidade, e propõe a necessidade de um diálogo com o que o contexto sócio-histórico pode revelar.

$\mathrm{O}$ volume se encerra com quatro resenhas de livros recentemente publicados, um deles como tradução brasileira de obras literárias hispano-americanas.

Adrián Pablo Fanjul

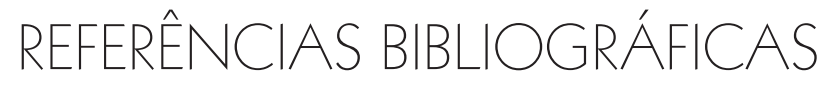

Benveniste, Emile. Problèmes de linguistique générale, 2. Paris: Gallimard, 1974. Pizarnik, Alejandra. Antologia Poética. Buenos Aires: Cántaro - Corregidor, 1997. 